\title{
Ethnologies
}

\section{Critical and Cultural Approaches to Space : An Introduction}

\section{Brian Rusted}

Volume 24, numéro 1, 2002

Espace

Space

URI : https://id.erudit.org/iderudit/006527ar

DOI : https://doi.org/10.7202/006527ar

Aller au sommaire du numéro

Éditeur(s)

Association Canadienne d'Ethnologie et de Folklore

ISSN

1481-5974 (imprimé)

1708-0401 (numérique)

Découvrir la revue

Citer cet article

Rusted, B. (2002). Critical and Cultural Approaches to Space : An Introduction.

Ethnologies, 24(1), 5-11. https://doi.org/10.7202/006527ar d'utilisation que vous pouvez consulter en ligne.

https://apropos.erudit.org/fr/usagers/politique-dutilisation/ 


\title{
Critical and Cultural Approaches to Space: AN INTRODUCTION
}

\author{
Brian Rusted \\ University of Calgary
}

... when we write about daily life now, we should think very carefully about whose daily life we are talking about. When we write about space, we should likewise think about whose space we mean (Merrifield 2000: 181).

Throughout the opening pages of his 1991 study of Calvert, Newfoundland, Gerald Pocius elaborates a distinctive argument about material culture and space. Although A Place to Belong is based on several decades of research on Newfoundland material culture, Pocius makes it clear that he does not share in a tendency of material culture research to isolate particular classes of objects and artifacts from the spatial and social activities that give them meaning. In order to tackle the "ethnography of cultural space" (1991: 11), he had "to start with space and discover the social relations that individual objects fostered within that space" (8).

What does such an ethnography of cultural space achieve? Pocius is unequivocal: reversing the analytic relation between material culture and space offers an investigative model for the social production of vernacular landscape and the spatial organization of consumption. The result gives the reader a glimpse into an ongoing dialogue between tradition and modernity. Calvert is not portrayed as a traditional community moving down the inevitable road to modernity, nor does Pocius merely reveal the quaint features of a geographic marginality. Pocius demonstrates how people appropriate the present in the ongoing articulation of their sense of spatial order. He also reveals the consequences of losing a sense of space and its social demands. 
As the ties of place generally weaken in any region, people increasingly create objectified signs of their culture, promoting item-oriented activities under rubrics like "folklore" and "heritage"(Pocius 1991: 23).

This research model lets him move towards what some might have identified a decade ago as a postmodern space in representation.

In the same year that A Place to Belong was published, Rob Shields published Places on the Margin, a linked collection of his essays that brought critical research traditions to bear on a variety of spatial case studies. Looking at topographic locations like the Canadian north or Brighton beach, Shields explores how such spaces acquire social significations and circulate as representations.

The social "Other" of the marginal and of the low cultures is despised and reviled in the official discourse of dominant culture and central power while at the same time being constitutive of the imaginary and emotional repertoires of that dominant culture (Shields 1991: 5).

Shields uses the phrase "social spatialization" to describe this discursive complex of spatial representations. Unlike the disciplinary emphasis that Pocius places on material culture and vernacular landscape, Shields sees his approach to space as contributing to "human geography, environmental psychology, and semiotics" (11), as he seeks antecedents from sociology and anthropology for dealing with the social labeling of space. Yet he too feels that prior research has contributed to space being analyzed as "context-less assemblages of objects" (26). Shields does not move towards an ethnography of cultural space. Drawing on Lefebvre, he turns instead towards "the culturally mediated reception of representations of environments, places, or regions which are 'afloat in society' as 'ideas in currency' " (14).

Why compare these books by way of introducing this collection of essays? I have stretched out the comparison for several reasons. First and foremost, Pocius and Shields suggest something of the range of spatial research encompassed by the individual projects in this issue. Their concurrent publication a decade ago is indicative of creative ferment happening in a variety of fields reengaging the concept of space. They demonstrate the broad, interdisciplinary currency that cultural research on space had and continues to have. Such scholarly work extends from the ethnographic study of quotidian practices (drawing predominantly on folklore, material culture, cultural geography, and 
landscape studies) to the critical analysis of spatial representations (emerging more from critical geography, sociology, and political economy). These two books also embody the polemic energy of spatial research in their respective fields, and they demonstrate some of the innovations of spatial research paradigms.

Given the diverse and often divergent disciplinary approaches to space, is it possible to trace common antecedents? This is another reason for comparing these two books: their publication in the same year undermines a tendency to imagine a linear narrative that describes how critical and cultural research on space has developed. The temptation is to imagine a progressive, monolithic development. It might start in some moment of high modernism with the positivist analysis of space conceived, in Foucault's often-cited phrase, as "the dead, the fixed, the undialectical, the immobile" (Foucault 1980: 70). This establishes a target for more engaged, qualitative research. Space might be seen first in terms of particular human experiences, then as reflective of social experience, and then perhaps as constitutive of social experience (Davies and Herman 1971). Some transformative encounter with a Marxist tradition of scholarship would then change the direction of research, relegating both positivist and qualitative projects to the back seat in the head-on confrontation with capitalism (Lefebvre 1974). The elaboration of a political economy of space in cultural studies proliferates into projects centred on race, class, and gender (Berry and Henderson 2002; Razack 2002; Kennedy 2000; Mohanram 1999; Ainley 1998; Ingram et al. 1997; Hayden 1995; Massey 1994), and space as the site of contestation or resistance (Sharp et al. 2000; Pile and Keith 1997). The formation of a postmodern periodization takes initial shape around conceptions of space as representation, perhaps first as discourse in a poststructural phase, but then maturing into a hyperreal space of simulation, or the globalized space of disjuncture and difference (Watson and Gibson 1995).

Certainly the outlines of the histories of critical geography proposed by Edward Soja (Soja 1989, but see Gregory 1990 and Philo 2000 for reappraisals) and others accord with such an imaginary narrative. The simultaneous publication of the volumes by Pocius and Shields suggests the need for a more heterogeneous view of histories and of the research programs in which the ongoing exploration of space and its synonyms take shape. Comparing these volumes points out exclusions that any such narrative entails. There is a tendency for critical traditions to push 
grounded, cultural and ethnographic research to the margins. Despite this, cultural landscape research has a well-developed sense of its own historical development (Groth 1997; Hayden 1995; Meinig 1979). It can trace some of its explicit and formative influences back to French geography though the early translations of J.B. Jackson (see Lefkowitz Horowitz 1997), and has continued to renew its engagement with critical theory (see Holdsworth 1997) effectively and productively. More broadly anthropological studies of space have been able to redress the urban tendency to minimize rural research (Cloke and Little 1997; Rotenberg and McDonough 1993; Ferguson and Gupta 1992). More significantly, these more broadly anthropological endeavors point to the reconceptualization of culture separated from spatial boundaries (Marcus and Myers 1995; Marcus 1994; Rosaldo 1988). As other areas of the social sciences took a renewed interest in space, anthropology critiqued its tendency to treat culture as isomorphic with space. New models to investigate transcultural forms of identity and the flow of culture through space have become increasingly important (Gupta and Ferguson 1992). Undoubtedly, the proliferation of new media forms of distribution has accelerated aspects of such spatial and cultural discontinuity (Acland 1999) but "for whom?" and "to what extent?" are still open questions (Massey 1994). The strength of these broadly cultural approaches to space is that they locate the social experience of space in terms of the body (Teather 1999) and they ground the political and economic consequences of space and its dislocations in terms of particular social formations (Burawoy 2000).

The essays in this collection share in and build on these imaginary narratives and redressed exclusions. They ground critical theory, they articulate the local, and they embody the particular experiences of space. They demonstrate the ongoing vitality of interrogating fundamental intellectual concepts. Perhaps most importantly they carry on the dialogue between ethnography, culture and space by writing it from the space of their own lives. To return to the quote that opens this introduction, they have thought carefully about whose life and whose space they mean. 


\section{References}

Acland, Charles. 1999. "Histories of Space and Power: Innis in Canadian Cultural Studies" in Harold Innis in the New Century: Reflections and Refractions, eds. Charles Acland and William Buxton. Montréal: McGill-Queen's University Press, 243-260.

Ainley, Rosa, ed. 1998. New Frontiers of Space, Bodies and Gender. New York: Routledge.

Berry, Kate and Martha Henderson, eds. 2002. Geographical Identities of Ethnic America: Race, Space and Place. Reno: University of Nevada Press.

Burawoy, Michael, Joseph Blum, Sheba George, Zsuzsa Gille, Teresa Gowan, Lynne Haney, Maren Klawiter, Steven Lopez, Sean O Riain, Millie Thayer. 2000. Global Ethnography: Force, Connections and Imaginations in a Postmodern World. Los Angeles: University of California Press.

Cloke, Paul and Jo Little, eds. 1997. Contested Countryside Cultures:

Otherness, Marginalisation and Rurality. Routledge: London.

Davies, D. Ioan and Kathleen Herman, eds. 1971. Social Space: Canadian Perspectives. Toronto: New Press.

Ferguson, James and Akhil Gupta, eds. 1992. "Theme Issue: Space, Identity, and the Politics of Difference". Cultural Anthropology 7:2, February, 3-129.

Foucault, Michel. 1980. Power/Knowledge: Selected Interviews and Other Writings, 1972-1977. Trans. and ed. C. Gordon. Brighton: Harvester Press.

Gregory, David. 1990. "Chinatown Part Three? Soja and the missing spaces of social theory," Strategies 3: 40-104.

Groth, Paul. 1997. "Bibliography: Basic Works in Cultural Landscape Studies", in Understanding Ordinary Landscapes, ed. Paul Groth and Todd Bressi. New Haven: Yale University Press, 243-260.

Gupta, Akhil and James Ferguson. 1992. "Beyond 'Culture': Space, Identity, and the Politics of Difference", Cultural Anthropology 7-1: 6-23.

Hayden, Dolores. 1995. The Place of Power: Urban Landscapes as Public History. Cambridge: MIT Press.

Holdsworth, Deryck. 1997. "Landscape and Archives as Texts" in Understanding Ordinary Landscapes, ed. Paul Groth and Todd Bressi. New Haven: Yale University Press, 44-55.

Ingram, Gordon et. al., eds. 1997. Queers in Space: Communities/Public Places/Sites of Resistance. Seattle: Bay Press. 
Kennedy, Liam. 2000. Race and Urban Space in Contemporary America. Edinburgh: Edinburg University Press.

Lefebvre, Henri. 1974. La production de l'espace. Paris: Éditions Anthropos.

Lefkowitz Horowitz, Helen. 1997. "J.B. Jackson and the Discovery of American Landscape" in J.B. Jackson's Landscape in Sight: Looking at America, ed. Helen Lefkowitz Horowitz. New Haven: Yale University Press, ix-xxvi.

Marcus, George. 1994. "The modernist sensibility in recent ethnographic writing and the cinematic metaphor of montage" in Visualizing Theory: Selected Essays from V.A.R. 1990-1994, ed. Lucien Taylor. London: Routledge, 37-53.

— and Fred Myers. 1995. The Traffic in Culture: Refiguring art and anthropology. Los Angeles: University of California Press.

Massey, Doreen. 1994. Space, Place and Gender. Cambridge: Polity Press. Merrifield, Andy. 2000. "Henri Lefebvre: A socialist in space" in Thinking Space, ed. Mike Crang and Nigel Thrift. London: Routledge, 167-182.

Mohanram, Radhika. 1999. Black Body: Women, Colonialism, and Space. Minneapolis: University of Minnesota Press.

Pile, Steve and Michael Keith, eds. 1997. Geographies of Resistance. London: Routledge.

Philo, Chris. 2000. "Foucault's Geography" in Thinking Space, ed. Mike Crang and Nigel Thrift. London: Routledge, 205-238.

Pocius, Gerald. 1991. A Place to Belong: Community Order and Everyday Space in Calvert, Newfoundland. Athens: The University of Georgia Press.

Razack, Sherene, ed. 2002. Race, Space, and the Law: The Making of Canada as a White Settler Society. Toronto: Between the Lines Press. Rosaldo, Renato. 1988. "Ideology, place and people without culture", Cultural Anthropology 3-1: 77-87.

Rotenberg, Robert and Gary McDonogh. 1993. The Cultural Meaning of Urban Space. London: Bergin \& Garvey.

Sharp, Joanne P. et al., eds. 2000. Entanglements of Power: Geographies of Domination/Resistance. London: Routledge.

Shields, Rob. 1991. Places on the Margin: Alternate Geographies of Modernity. London: Routledge.

Soja, Edward. 1989. Postmodern Geographies: The Reassertion of Space in Critical Social Theory. London: Verso. 
Teather, Elizabeth. 1999. Embodied Geographies: Spaces, Bodies and Rites of Passage. London: Routledge.

Watson, Sophie and Katherine Gibson, eds. 1995. Postmodern Cities and Spaces. Oxford: Blackwell. 